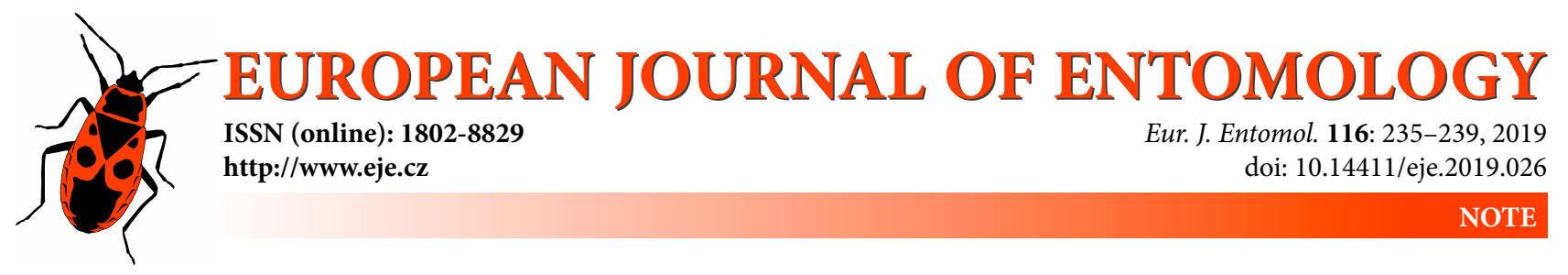

\title{
First record of Azalea rough bollworm, Earias roseifera (Lepidoptera: Nolidae) in Europe
}

\author{
Andrea TADDEI ${ }^{1}$, Andrea TANTARDINI ${ }^{1}$ and KeItARo EDA ${ }^{2}$ \\ ${ }^{1}$ Regione Lombardia, Servizio Fitosanitario Regionale, Laboratorio fitopatologico, c/o Fondazione Minoprio, Viale Raimondi 54, \\ 22070 Vertemate con Minoprio (Como), Italy; e-mails: a.taddei@fondazioneminoprio.it, \\ andrea_tantardini-FITOLAB@regione.lombardia.it \\ 2 1-27-16, Taru-machi, Kouhoku-ku, Yokohama, Kanagawa Prefecture 222-0001, Japan; e-mail: eda@air.ocn.ne.jp
}

Key words. Lepidoptera, Nolidae, Azalea rough bollworm, Earias roseifera, first record, Europe, Italy, Rhododendron, DNA barcoding

\begin{abstract}
The first record of the Azalea rough bollworm, Earias roseifera Butler, 1881 in Europe is reported. Larvae were collected on twigs, sprouts and buds of several azalea hybrids growing in a botanical garden in the province of Como (Northern Italy). The larvae fed mainly on the flower and vegetative buds, which resulted in a significant reduction in the amount of blossom. Specimens were identified using both morphological characters and a molecular analysis of the DNA barcode (COX1 sequence).
\end{abstract}

\section{INTRODUCTION}

The genus Earias Hübner, 1825 includes 49 species and two subspecies that are widespread in temperate and tropical regions in Asia and Australia (Poole, 1989; Holloway, 2003). Many of these species are pests of Ericaceae, Malvaceae and Solanaceae and are often found in Europe on fresh plant products imported from several African and Asian countries, as often happens for E. vittella (Fabricius, 1794) and E. insulana (Boisduval, 1833) on fresh okra fruits (Abelmoschus esculentus (L.) Moench) (Malumphy \& Robinson, 2002; Ali et al., 2016).

Fibiger \& Hacker (2005) list five European species of Earias: E. clorana (Linnaeus, 1761) feeding on species of Salix (Matov \& Kononenko, 2012), E. albovenosana Oberthür, 1917, E. syriacana Bartel, 1903, E. vernana (Fabricius, 1787) feeding on Populus alba L., 1753 and E. insulana (Boisduval, 1833) feeding on species of Ceratonia and Gossypium (Kononenko \& Pinratana, 2013). The African taxon E. biplaga Walker 1866, a pest on cotton (Gossypium L., 1753), has been recorded four times in Europe, probably as a migrant: three times in England and once in Denmark (Goater, 1994; Fibiger \& Hacker, 2005).

In Japan, the Azalea rough bollworm, Earias roseifera Butler, 1881 (Lepidoptera: Noctuoidea: Nolidae: Eariadinae) is a pest of species of Rhododendron (Japanese Society of Applied Entomology and Zoology, 2006), in particular, several azalea hybrids. This moth was described in Tokyo in 1881 and, until now, it was found only in East Asia (Kishida, 2011; Kononenko \& Pinratana, 2013). The larvae of E. roseifera feed on flower and leaf buds causing a reduction and, in some cases, the complete absence of flowers. In Watabiki \& Yoshimatsu (2017), under both natural and rearing conditions, its larvae were observed feeding on the hymenium on the surface of leaf galls on Rhododendron sp. induced by Exobasidium sp., sometimes also on the leaf gall. Adults occur from April to September (bivoltine) (Kishida, 2011) and pupae overwinter in a tough cocoon on twigs of the food plant. The cocoon is dull white, flatter than the usual boat-shaped ones, with a slightly oblique anterior end (Yamamoto, 1987).

In Japan, Kaneko et al. (1988) report that Rhododendron japonicum (A. Gray) Suringar flower buds blighted by the fungus Pycnostysanus azaleae (Peck) Mason are often associated with the damage caused by Earias roseifera.

In Europe, azalea hybrids are widely planted ornamental shrubs in parks and gardens and widely cultivated in nurseries (Ghisleni \& Careaffini, 1985; Biraghi, 1995; Scariot et al., 2006). The climate around the northern Italian lakes is perfectly suited to magnolias, camellias and azaleas, which thrive in the woodland gardens of well-known Villas, like Villa Carlotta on Lago di Como, Villa Taranto on Lago Maggiore, or parks, like Parco Piacenza in Biella Province (Johnson, 1982; Van Gelderen \& Van Hoey Smith, 2005; Cox, 2018).

Since 2016, flowers of azalea hybrids at different sites in Como province have shown signs of damage in terms of necrosis of the apical buds, together with the surrounding young leaves, whereas the rest of the plant is green and healthy. The affected buds were both flower and vegetative buds. The apical buds appeared reddish-brown in colour, completely dried out, and there was a circular hole in each of the dead flower buds, indicating that an insect had been feeding. Frass was present at the bases of the young sprouts, but it was not possible to find the insect causing the damage.

In 2017 and 2018, further investigations were carried out in parks and gardens where azaleas are widely present, in order to obtain some specimens of the yet-unknown phytophagous insect. Several larvae were found on azalea hybrids in a private woodland garden, reared to the adult stage and submitted to both morphological and molecular analysis for identification. 
Morphological examination of the genitalia and molecular data were used to identify the pest. This insect was restricted to the area of 500 square meter belonging to that private woodland garden, but previous years observations suggested that the insect occurred in a wider area in the Como province.

In this paper, we report the first occurrence of E. roseifera in Europe. Moreover, we provide genetic barcoding sequences for the Italian specimens.

\section{MATERIAL AND METHODS}

\section{Collection and rearing}

Larvae feeding on buds and young sprouts were collected from azalea hybrids (Rhododendron spp.) growing in a botanical garden in the Como province (45.721754 N, 9.083785 E; Lombardia, Italy), from the beginning of June to the end of September 2018. Simultaneous presence of larvae of different instars indicate that egg-laying by adults occurs over a long period of time.

Neither larvae, nor signs of infestation by larvae were found on Rhododendron arboreum, $R$. ponticum and $R$. catawbiense. Some of the larvae were placed on potted azaleas inside net cages and reared in a laboratory at around $24^{\circ} \mathrm{C}$ and under a natural day-night cycle. Some larvae were preserved in $70 \%$ ethanol and adults pinned (Fig. 1). Seven adults were sent to the third author in Japan for identification based on examination of the genitalia.

\section{Morphological identification of adults}

Before examining the structure of the genitalia the adults' abdomens were removed and placed in $5 \% \mathrm{KOH}$ solution, then transferred to a petri dish with $70 \%$ ethanol and dissected under a binocular microscope. Slides of the genitalia were prepared and stained with Chlorazol Black using standard methods; all parts were slide-mounted in Euparal.

Original description by Butler (1881) (type locality Japan, Tokyo), together with other sources (Warren, 1907; Sugi, 1982; Kononenko \& Han, 2007; Kononenko, 2010; Kononenko \& Pinratana, 2013; Watabiki \& Yoshimatsu, 2018), were used for identification. Adult specimens of $E$. roseifera from Keitaro Eda's personal collection (including specimens collected near the type locality for E. roseifera) were used for comparison: Males: Kitazawa, Setagaya-ku, Tokyo, Japan, 13.v.1966, Y. Kishida leg.; Tama Kyuryo, Tokyo, Japan, 27.vi.1958, T. Maenami leg. Females: Kitazawa, Setagaya-ku, Tokyo, Japan, 10.vii.1984, Y. Kishida leg.; Nippara, Okuyama, Tokyo, Japan, 2.viii.1976, Y. Kishida leg.

\section{DNA extraction and amplification}

Ten specimens were analyzed using molecular techniques. DNA was purified using Zymo Tissue \& Insect Miniprep Kit (Zymo Research Corporation, Irvine, CA), after specimens were disrupted using a TissueLyser (Qiagen, Hilden, Germany). Primer pair LCO1490/HCO2198 (Folmer et al., 1994) was used for amplification of a $658 \mathrm{bp}$ fragment of the mitochondrial cytochrome $\mathrm{c}$ oxidase gene, subunit 1 (COX1). PCR mix had a total volume of $25 \mu \mathrm{l}$ and contained $3 \mathrm{mM} \mathrm{MgCl}$, each primer at a concentration of $400 \mathrm{nM}, 0.4 \mathrm{mM}$ dNTPs, $1 \mu 1$ of genomic DNA and 1 unit of TaqDNA polymerase (GoTaq G2 Flexi, Promega, Madison, WI). The thermocycling profile consisted of one cycle of 3 min at $94^{\circ} \mathrm{C}, 35$ cycles of $45 \mathrm{~s}$ at $94^{\circ} \mathrm{C}, 45 \mathrm{~s}$ at $50^{\circ} \mathrm{C}$ and $45 \mathrm{~s}$ at $72^{\circ} \mathrm{C}$, with a final elongation step of $5 \mathrm{~min}$ at $72^{\circ} \mathrm{C}$.

Amplification products were sent for Sanger sequencing using both the forward and reverse primers (GATC Biotech, Koeln, Germany). Consensus sequences were edited using Geneious v.11.01 (Biomatters, Auckland, New Zealand).
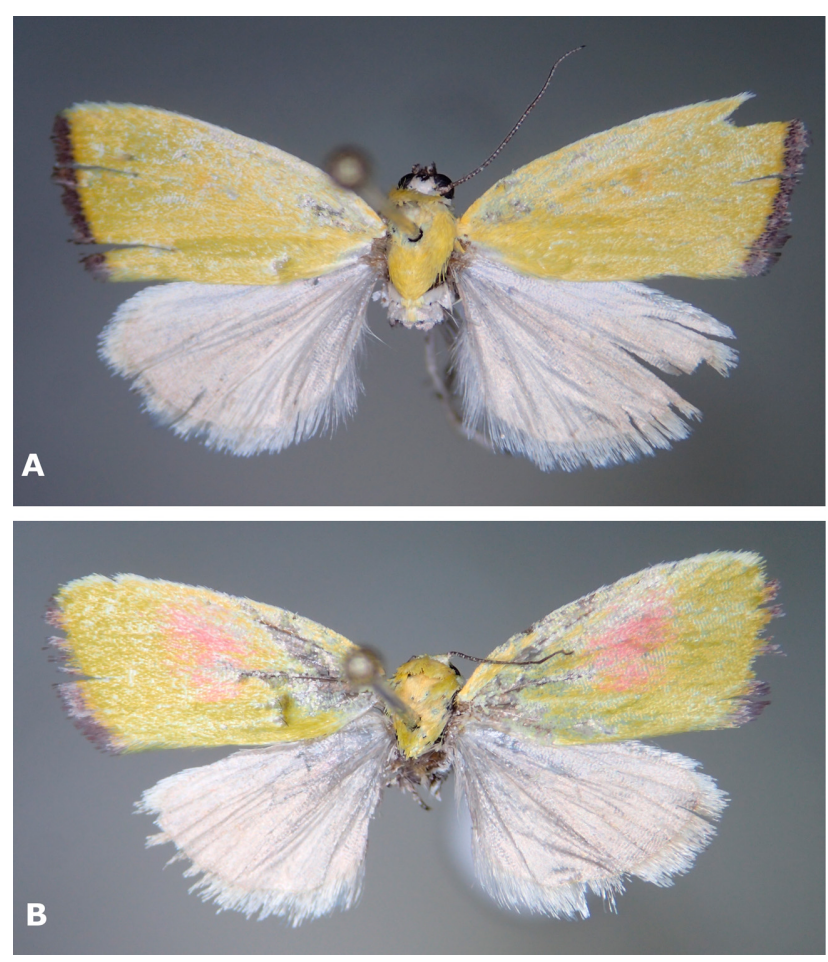

Fig. 1. E. roseifera adults. A - reared male (Eros18_A07); B reared female (Eros17_A01).

Sequences were searched against the BOLD Systems v. 4 and GenBank databases in order to determine the closest match and confirm the identification based on morphological traits.

A neighbour-joining tree was built using Kimura 2-parameter model (MEGA v.7.0) and included available sequences of $E$. roseifera Butler, 1881, E. roseoviridis Sugi, 1982, E. cupreoviridis (Walker, 1862) and E. dilatifemur Sugi, 1982, from different Japanese localities (Akuseki-jima Is., Amami-oshima Is., Ibaraki Pref., Kuchinoerabu-jima Is., Kuchino-shima Is., Nakano-shima Is., Okinawa-jima Is., Saitama Pref., Takara-jima Is., Wakayama Pref., Yaku-shima Is., Yamagata Pref.) and from Laos (Watabiki \& Yoshimatsu, 2018).

\section{RESULTS}

\section{Larval behaviour}

Under laboratory conditions, mature larvae quickly pupated and developed into adults, providing a chance to observe the whole life cycle, from one generation to the next. After emergence, adults laid eggs close to buds of potted azalea hybrids in cages (Fig. 2A). Newly hatched larvae burrowed immediately into the buds and young sprouts. At this stage the only sign of the infestation was the ejected pile of frass on the leaves surrounding the bud (Fig. 2B). On reaching a larger size, larvae exited the plant tissues and moved quickly from bud to bud and chewed a circular hole in each bud. At this stage, larvae were entirely visible, except for their head, which was inside a bud (Fig. 2C and D). Attacked buds were completely emptied and died. Occasionally, leaves were also partially eaten by the larvae. At maturity, larvae spun a silky white cocoon on the stems of the host plant (Fig. 2E, F).

\section{Morphological identification of adults}

The Italian specimens were identified as Earias roseifera Butler, 1881, based on the morphological features of genitalia, clypeus and antennae (Watabiki \& Yoshimatsu, 2018). Watabiki \& Yoshimatsu (2018) note that E. roseifera and E. roseoviridis are 

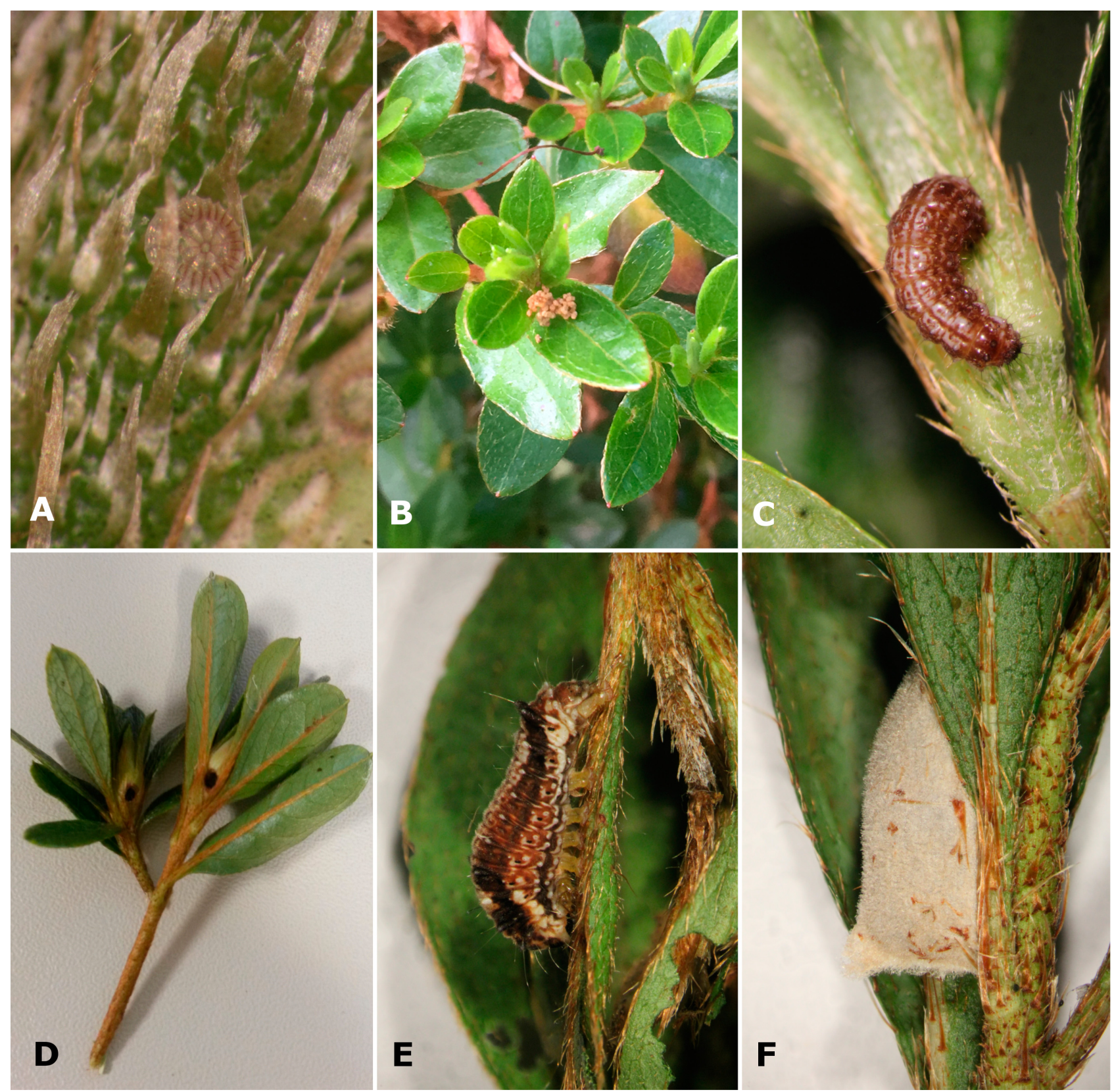

Fig. 2. E. roseifera. A - eggshell on stem of azalea plant, close to a bud; $B$ - ejected frass pile on the leaves surrounding the bud, the larva is inside the bud; C - fully-grown larva with its head inside a bud; D - circular holes in buds made by feeding larvae; $E$ - mature larva prepared for cocoon spinning; F - silky cocoon.

not completely distinguishable on the basis of their genital morphology, but can be by morphological differences in their antennae and clypeus.

The following morphological features were examined.

Male genitalia (Fig. 3A) figured by Sugi (1982), Kononenko \& Han (2007) and Watabiki \& Yoshimatsu (2018). Uncus bifid and acute. Valva wide, with dorsal lobe, ventrally directed long spine. Costa with digitus lobe. Aedeagus slender.

Female genitalia (Fig. 3B) figured by Kononenko \& Han (2007) and Watabiki \& Yoshimatsu (2018). Ductus bursae weakly membranous. Appendix bursae round. Corpus bursae fusiform, strongly ribbed.

Antennae generally greyish brown, with white stripes in basal half (Fig. 4A); colour of the scales near the eyes on the clypeus uniformly whitish-yellow (Fig. 4B).

\section{Molecular analysis}

The 658 bp long barcoding sequence for COX1 was obtained for all ten specimens. Two haplotypes, differing in only one nucleotide, were discovered.

The sequences showed an identity of $99-100 \%$ with the $E$. roseifera sequences available in the GenBank database. No close match with $E$. roseifera sequences was obtained in BOLD Systems, due to lack of reliable reference sequences for this species in the BOLD database. The sequences obtained were submitted to the GenBank database and represent the first sequences of $E$. roseifera specimens found outside of its native range (Accession Numbers LR131828-LR131829).

The neighbour-joining tree (Fig. 5) showed that the two Italian haplotypes cluster together with the Japanese specimens collected in different prefectures, recently made available by Watabiki \& Yoshimatsu (2018). 

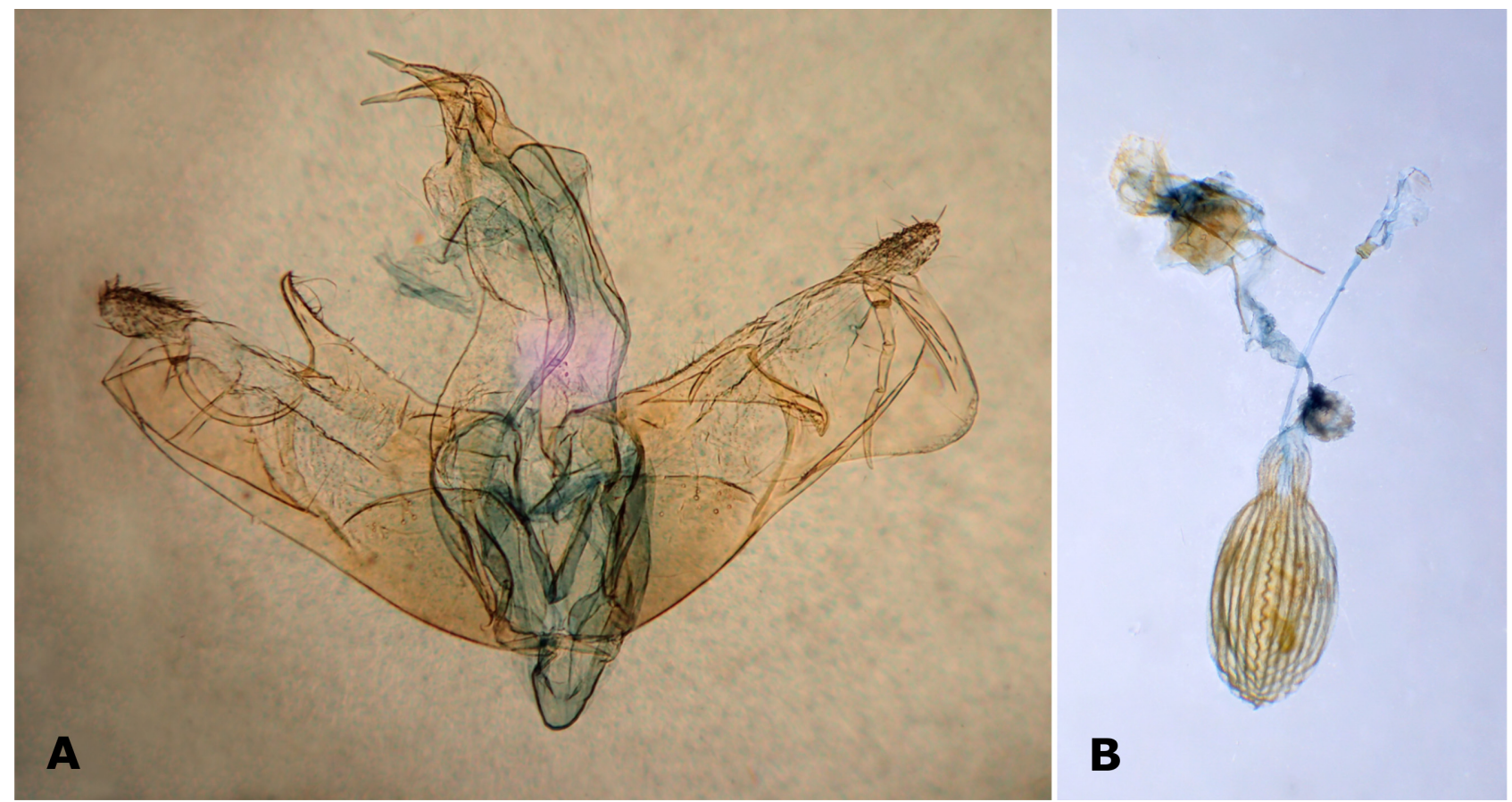

Fig. 3. E. roseifera. A - male genitalia (Eros18_A07, slide KE-2102); B - female genitalia (Eros17_A01, slide KE-2103).

\section{DISCUSSION}

Since 2016, damage caused by an unknown lepidopteran species was observed on azalea shoots and buds in different botanical gardens in Como province. These larvae were successfully reared to adults under laboratory conditions and identified as Earias roseifera Butler, 1881, using both morphological and molecular analyses. This is the first official record of the presence $E$. roseifera in Europe, according to the available literature and official reports in the European Plant Protection Organization (EPPO Global Database). Until now, the known distribution of this insect was limited to Japan, Korea, Thailand, Taiwan and South of Russian Far East (Kononenko \& Pinratana, 2013). Watabiki \& Yoshimatsu (2018) raise some doubts about the correct identification of E. roseifera in Kononenko \& Pinratana, 2013 and, therefore, its presence in Thailand. The most likely way this insect was introduced into Italy is on imported potted azalea plants harbouring some pupae, which would easily pass unnoticed in their cocoons. Italy is the largest European importer of azaleas from Japan and, in general, from Eastern Asia (Hübner, 2018, provisional data for year 2017).

The cultivation of Ericaceae is very popular in Northern Italy and azalea hybrids are often the main attraction in the formal gardens around the pre-alpine lakes, which are visited by tens of thousands of visitors and tourists every year when the azaleas are in flower. In addition, azaleas are often propagated in Italian nurseries. E. roseifera larvae feed on azaleas by burrowing into the buds and young sprouts, which results in a loss of flower buds which may be considerable even at low abundance of this insect, because a single larva can destroy many buds (authors' personal observation). Therefore, an unmanaged infestation in a botanical garden could cause a significant reduction in the quantity of flowers and seriously affect the attractiveness for visitors. Likewise, an infestation in a nursery would imply extra costs for the insecticide treatments necessary to avoid the economic loss associated with producing plants of low commercial value.

Further studies are needed to clarify the biological cycle of $E$. roseifera in Northern Italy and its effect on different azalea hybrids. There is a need to monitor its spread in Italian botanical gardens, parks and nurseries. Since larvae are inside the azalea buds for the first part of their life cycle, the early detection of juvenile stages is not always straightforward. However, the presence of a circular hole in the buds is a clear sign of an infestation with the Azalea rough bollworm, which is useful for monitoring purposes.
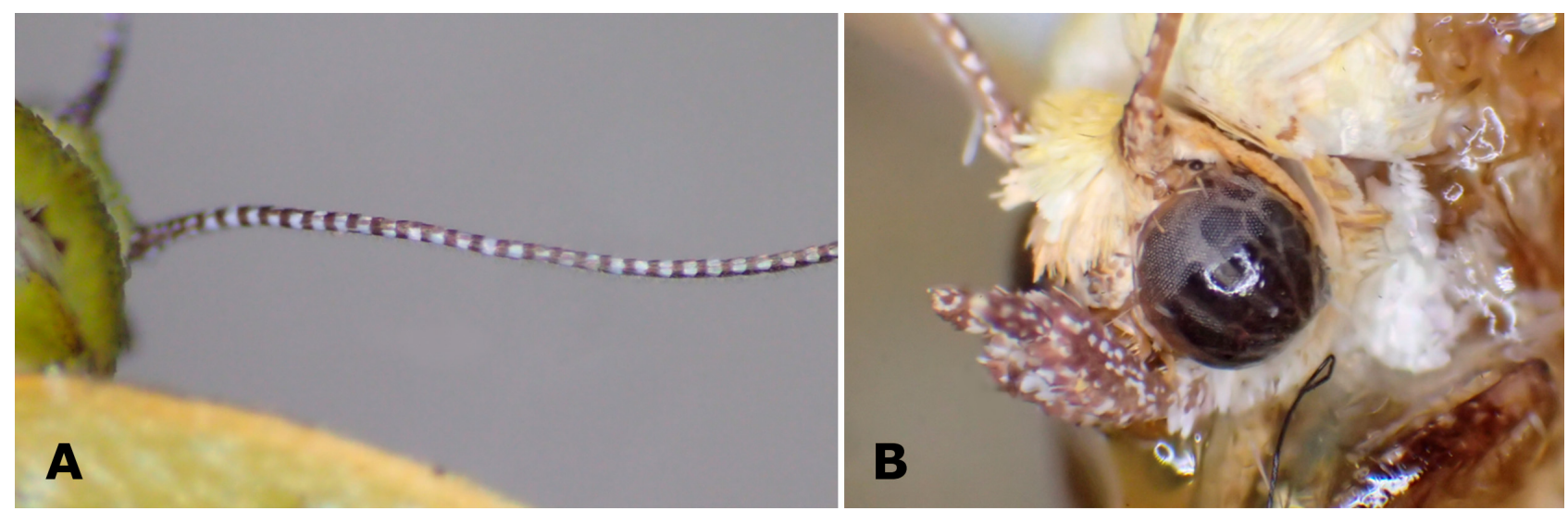

Fig. 4. E. roseifera. A - female, right antenna in dorsal view; B - male, left side of head in lateral view. 


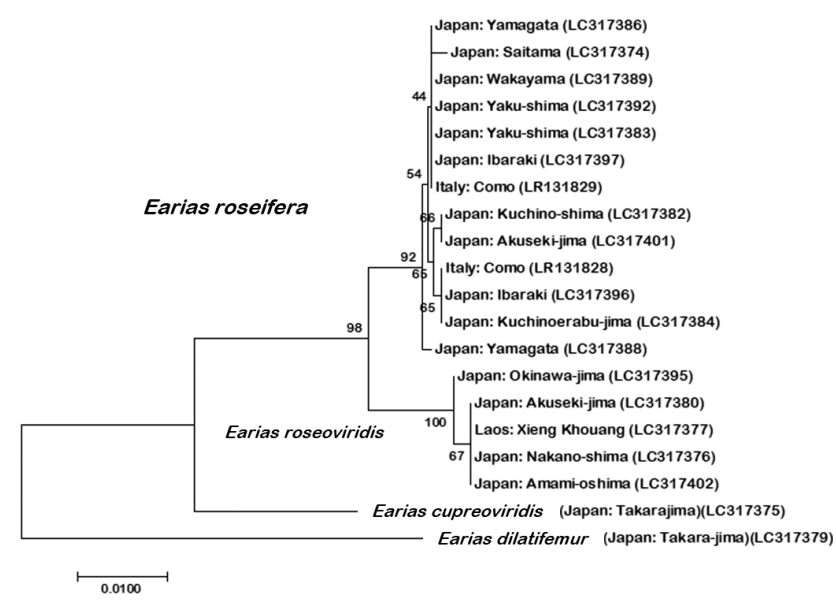

Fig. 5. Neighbour-joining tree (MEGA v.7.0, Kimura 2-parameter model, bootstrap test 1000 replicates, outgroups LC317375 E. Cupreoviridis and LC317379 E. dilatifemur).

ACKNOWLEDGEMENTS. We would like to thank M. Boriani (Regione Lombardia, Servizio Fitosanitario Regionale) for support and critical reading of this paper. Special thanks to S. Taddei (Master Degree in Japanese Language and Culture, Cà Foscari University, Venice) for the translations of the Japanese papers.

\section{REFERENCES}

Ali A., Nizamani I.A., Rajput Z.I., Khanzada M.A. \& Shah A.H. 2016: Monitoring of spotted bollworm (Earias spp.) through light trap in okra crop at tando jam. - Sci. Int. (Lahore) $\mathbf{2 8}$ : $4677-4689$.

Biraghi C. 1995: Avversità delle Acidofile Ornamentali. Ace International Flortecnica, Garbagnate Monastero, 208 pp. [in Italian].

ButLER A.G. 1881: Descriptions of new genera and species of heterocerous Lepidoptera from Japan. - Trans. Entomol. Soc. Lond. 29: 579-600.

Cox K. 2018: Woodland Gardening with Rhododendrons, Magnolias, Camellias and Acid-Loving Plants. Glendoick, Glencarse, $394 \mathrm{pp}$.

Fibiger M. \& Hacker H. 2005: Systematic list of the Noctuoidea of Europe (Notodontidae, Nolidae, Arctiidae, Lymantriidae, Erebidae, Micronoctuidae, and Noctuidae). - Esperiana 11: 93-205.

Folmer O., Black M., Hoen W., Lutz R. \& Vrijenhoek R. 1994: DNA primers for amplification of mitochondrial cytochrome $\mathrm{c}$ oxidase subunit I from diverse metazoan invertebrates. - Mol. Mar. Biol. Biotechnol. 3: 294-299.

Ghisleni P. \& CAREAFFini B. 1985: Rododendri e Azalee. Edagricole, Milano, 212 pp. [in Italian].

Goater B. 1994: The genus Earias Hübner, (1825) (Lepidoptera: Noctuidae) in Britain and Europe. - Entomol. Rec. 106: 233 239.

Holloway J.D. 2003: The Moths of Borneo. Part 18. Southdene Sdn. Bhd., Kuala Lumpur, 279 pp.

HüBner S. 2018: International Statistics: Flower and Plants 2018. Vol. 66. International Association of Horticultural Producers (AIPH), Oxford, 202 pp.
Japanese Society Of Applied Entomology And Zoology 2006: Major Insect and Other Pests of Economic Plants in Japan. (Rev. Ed.). Japanese Society of Applied Entomology and Zoology, Tokyo, 387 pp. [in Japanese with English and Latin indices].

Johnson H. 1982: La Cura del Giardino. Istituto grafico De Agostini, Novara, 272 pp. [in Italian].

Kaneko S., Yokozawa Y. \& Kubono T. 1988: Bud blight of Rhododendron trees caused by Pycnostysanus azaleae. - Ann. Phytopath. Soc. Japan 54: 323-326.

Kishida Y. 2011: Chloephorinae. In Kishida Y. (ed.): The Standard of Moths in Japan II. Gakken Education Publishing, Tokyo, pp. 186-186 [in Japanese].

Kononenko V.S. 2010: Micronoctuidae, Noctuidae: RivulinaeAgaristinae (Lepidoptera). Noctuidae Sibiricae. Vol. 2. Entomological Press, Sorø, $475 \mathrm{pp}$.

Kononenko V.S. \& Han H.L. 2007: Atlas Genitalia of the Noctuidae in Korea (Lepidoptera). (Insects of Korea 11). Korean National Arboretum \& Center for Insect Systematics, Seoul, $461 \mathrm{pp}$.

Kononenko V.S. \& Pinratana B.A. 2013: Moths of Thailand 3. Part 2, Noctuoidea. Brothers of Saint Gabriel in Thailand, Bangkok, $625 \mathrm{pp}$.

Malumphy C. \& Robinson J. 2002: Lepidopterous larvae intercepted on imported produce of fresh bean, pea, okra, sweet pepper, aubergine and tomato fruit in England and Wales between 1970 and 2000. — Entomol. Gaz. 53: 191-202.

Matov A.Yu. \& Kononenko V.S. 2012: Trophic Connections of the Larvae of Noctuoidea of Russia (Lepidoptera, Noctuoidea: Nolidae, Erebidae, Euteliidae, Noctuidae). Dal'nauka, Vladivostok, 347 pp. [in Russian].

Poole R.W 1989: Lepidopterorum Catalogus (New Ser.). Fascicle 118, Noctuidae Part 1. E.J. Brill, Leiden, 500 pp.

Scariot V., Remotti D. \& Merlo F. 2006: Le Azalee Sempreverdi del Lago Maggiore. Supplement No. 50 of "Quaderni della Regione Piemonte - Agricoltura”. Regione Piemonte - Assessorato Agricoltura, Torino, $334 \mathrm{pp}$. [in Italian].

Sugi S. 1982: Earias roseifera Butler. In Inoue H., Kuroko H., Moriuchi S. \& Kawabe A. (eds): Moths of Japan. Kodansha, Tokyo, Vol. 1: 796-797, Vol. 2: 378, pls 194, 371 [in Japanese]. Van Gelderen D.M. \& Van Hoey Smith J.R.P. 2005: Rhododendrons. Timber Press, Portland, OR, 424 pp.

WARren W. 1907: Genus Earias. In Seitz A. (ed.): The Macrolepidoptera of the World 3. Alfred Kernen, Stuttgart, pp. 295296, pl. 53i.

Watabiki D. \& Yoshimatsu S. 2017: First report of the fungivorous habit of azalea rough bollworm, Earias roseifera Butler (Lepidoptera: Nolidae). — Jpn. J. Entomol. (N.S.) 20(2): 49-55 [in Japanese].

Watabiki D. \& Yoshimatsu S. 2018: Taxonomic relationship between Earias roseifera Butler and Earias roseoviridis Sugi (Lepidoptera: Nolidae: Eariadinae) with reference to their distributions mainly in Japan. - Lepidopt. Sci. 69: 11-18.

ҮАмамото M. 1987: Earias roseifera Butler. In Sugi S. (ed.): Larvae of Larger Moths in Japan. Kodansha, Tokyo, p. 217, pl. 105: 2 [in Japanese].

Received January 18, 2019; revised and accepted May 25, 2019 Published online July 11, 2019 